\title{
Age and Composition of Carbonatite Kimberlite Dykes in the Prince Charles Mountains, East Antarctica
}

\author{
Boris V. Belyatsky', Anton V. Antonov², Nickolay V. Rodionov' ${ }^{2}$, Anatoly A. Laiba ${ }^{3}$ and \\ Sergey A. Sergeev ${ }^{2}$ \\ ${ }^{l}$ VNIIOkeangeologia, Antarctic Geology Department, St.-Petersburg, Russia \\ ${ }^{2}$ VSEGEI, Centre for Isotope Research, St.-Petersburg, Russia \\ ${ }^{3}$ Polar Marine Geosurvey Expedition, Lomonosov, St.-Petersburg, Russia
}

In 1989 in the central part of the Prince Charles Mountains (East Antarctica) - the Fisher Massif, there was discovered a dyke of "carbonatite kimberlites" (Egorov et al., 1993) (Fig.1). Kimberlite dyke 20 - 25 $\mathrm{cm}$ wide (Fig.2a) crops out on the south-eastern slope of the massif where it makes an interrupted band about $450 \mathrm{~m}$ long and cuts Meso-Proterozoic metadiorites. General dyke strike is of meridianal direction with dip angle about $20^{\circ}-50^{\circ}$ to the west. By paleomagnetic data and chemical affinity to alkaline-ultramafic rocks of Jetty Peninsula the age of kimberlites is estimated as possibly Cretaceous.

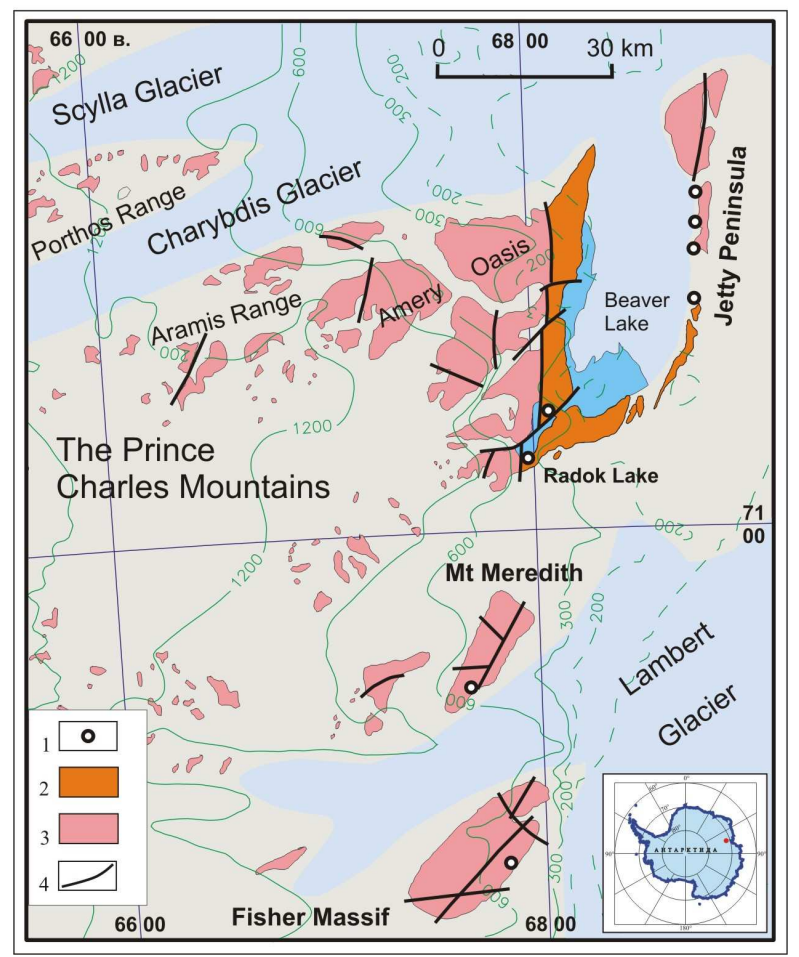

Fig. 1 Geological sketch map showing occurrences of alkaline-ultramafic rocks in the northern and central parts of the Prince Charles Mountains: 1 - Jurassic-Cretaceous alkaline picrites; 2 - Permian-Triassic coal-bearing deposits; 3 - Precambrian rocks; 4 - faults.

Kimberlites are represented by green to pale-green aphanitic rocks with some layering and globular texture (Fig.2b). Carbonate kimberlites are composed by phlogopite phenocrysts (up to $10 \%$ ), single grains of green mica, olivine and magnetite, all these minerals are placed into fine-grained phlogopite-magnetite- calcite-olivine matrix with an admixture of apatite, chromite and serpophite. The rock has lens-layered texture represented by alternation of light and dark stripes with different amount of calcite and colour minerals which have different morphology and size (Fig.2). The interstices are made up mainly by calcite. Its share is $25-60 \%$ in light layers and $80-90 \%$ in schlieren of globular texture. There are distinguished primary magmatic and metasomatic types of calcite. Kimberlites from the Fisher Massif in their general features are similar to the carbonate-rich kimberlite rocks of the Benfontein Lower Sill, South Africa (Dawson, Hawthorne, 1973; Egorov et al., 1993).

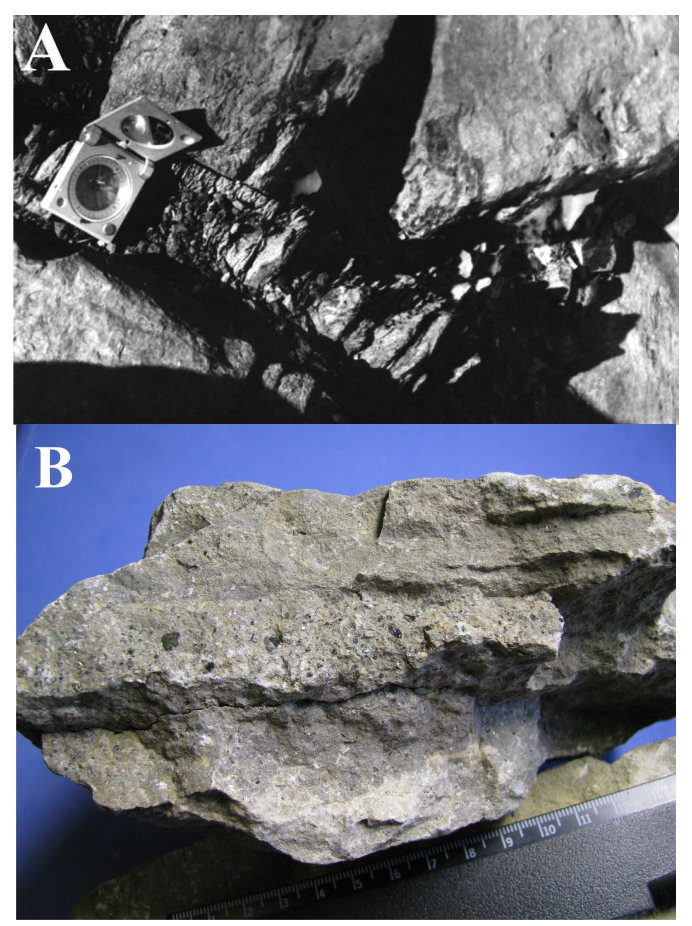

Fig. 2 Carbonatite kimberlite from the Fisher Massif. A kimberlite dyke cuts proterozoic metadiorites; B - typical view of the layered carbonatite kimberlite, the central part is enriched by calcite ocelli and phlogopite.

Calcite from matrix as well from ocelli contains up to 0.5 of $\mathrm{SrO}, 0.45 \mathrm{FeO}, 0.6 \mathrm{MnO}$ and 0.6 wt.\% $\mathrm{MgO}$. Compositional zoning of phlogopite phenocrysts (Fig.3b) shows $\mathrm{MgO}$ decreasing from 23 (core) to 21 wt.\% (rim), $\mathrm{Al}_{2} \mathrm{O}_{3}$ increasing from 11 to16, $\mathrm{TiO}_{2}$ increasing from 4.2 to $6.5, \mathrm{FeO}$ decreasing from 8.3 to $7.2 \mathrm{wt} . \%$. The silicate minerals from groundmass and 

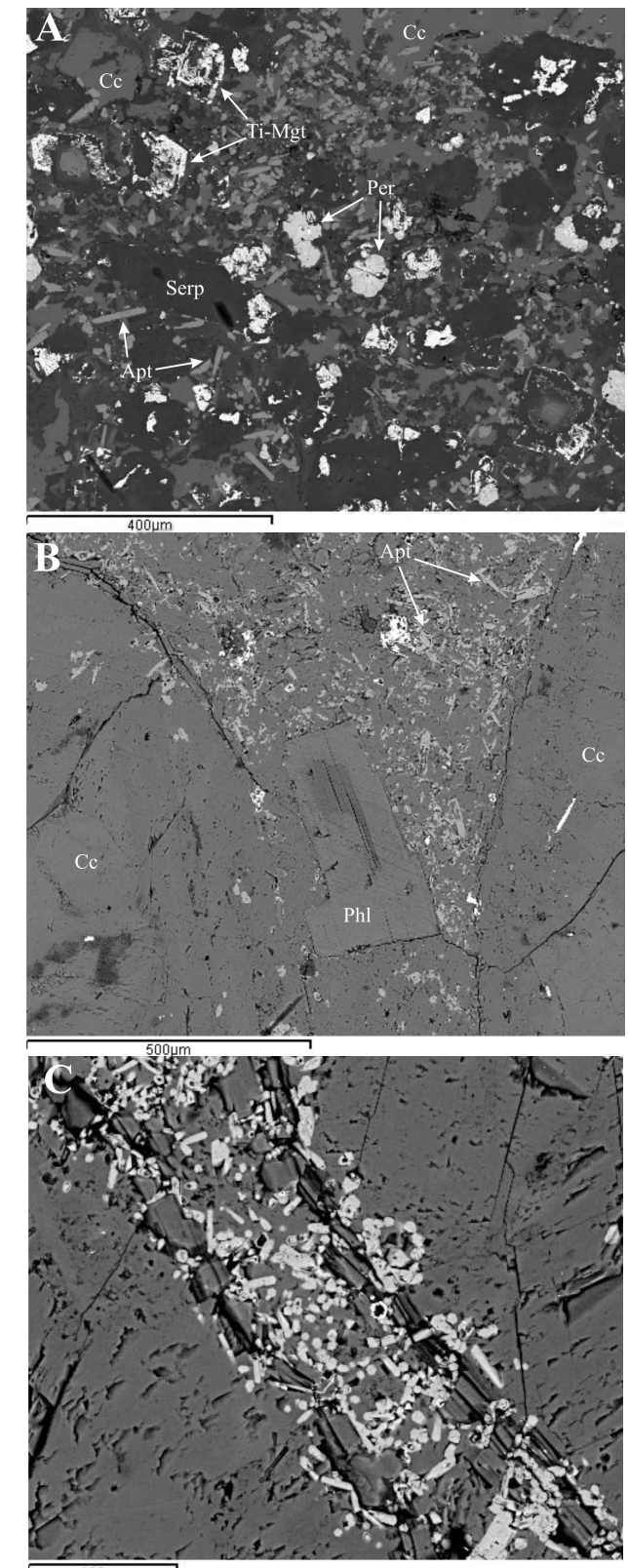

Fig. 3 Back-scattered electron images. A - groundmass of silicate rich bound of the dyke; $\mathrm{B}$ - phlogopite phenocrist between calcite ocelli; $\mathrm{C}$ - needle-like apatite grains filling the later zone between calcite ocelli; Cc - calcite, Ti-Mgt titanomagnetite, Per - perovskite, Phl - phlogopite, Serp serpentine, Apt - apaptite.

phenocrysts are totally replaced by phylosilicates. The most common phase of calcite-serpentine matrix is prismatic elongated apatite up to $100 \mu \mathrm{m}$ in size and "clean" composition (only $\mathrm{OH}$ and $\mathrm{Cl}$ up to 0.2 wt.\%) (Fig.3c). Other wide spread accessory mineral is titanomagnetite forming anhedral and spongy grains as well as rims around former primary silicates (e.g. olivine, diopside). The characteristic mineral for kimberlite rocks - perovskite, is scattered in silicate rich part of the kimberlite dyke (Fig.3a). Perovskites are presented by corroded and cracked crystals less than $100 \mu \mathrm{m}$ in size. Cores of perovskite grains are enriched in Th (up to 2 wt.\% of $\mathrm{ThO}_{2}$ ), besides this perovskite contains up to 3 wt. $\%$ of $\mathrm{Ce}_{2} \mathrm{O}_{3}, 1.5$ wt.\% $\mathrm{Nb}_{2} \mathrm{O}_{5}$ and 3 wt.\% $\mathrm{FeO}_{\text {tot }}$. Mantle-derived xenocrysts are vivery rare, and were found only by fully automated mineralogical probe analysis of thin sections. They are represented by: pyrope, chromite and ilmenite, and are not yet analysed quantitatively.

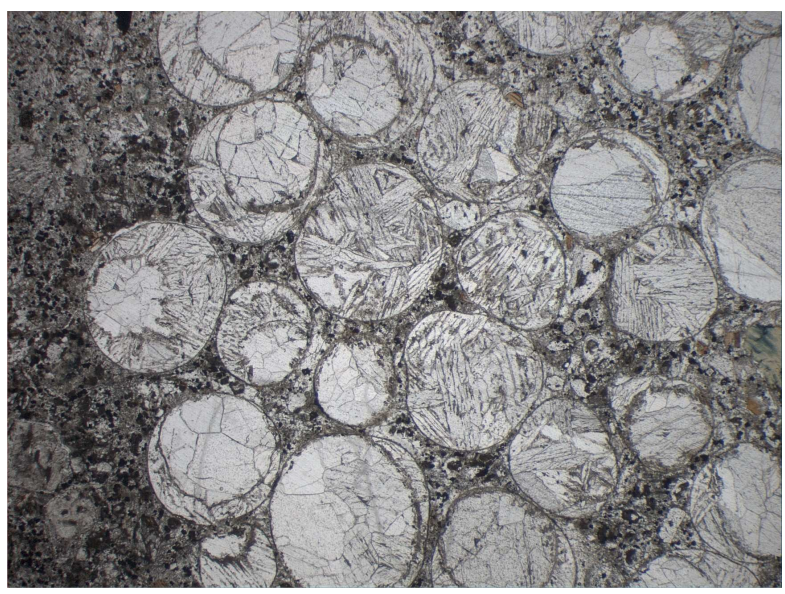

Fig. 4 Photomicrograph of orbicular carbonate-rich layer. Plane polarized light, view size is about $18 \mathrm{~mm}$. The most remarkable feature of this kimberlite dyke is a layer enriched in carbonate spherules up to $2-3 \mathrm{~mm}$ in size. That is not unique for carbonatites worldwide (Lapin, Vartiainen, 1983) as well as carbonatitic kimberlites (Dawson, Hawthorne, 1973; Haggerty, Fung, 2006) and according to experiment results (Kjarsgaard, Hamilton, 1988). It has been suggested that such phenomenon reflects immicsibility of carbonate and silicate liquids, but in our case some properties (existance of inner meniscus in some globules, absence of coalescent effects, identical carbonate composition in spherules and matrix, etc.) of the calcite ocelli require more complex evolution of carbonatite kimberlite system.

Chemical composition of rocks is characterized by considerable variations of the major components (wt.\%): $\mathrm{SiO}_{2}: 8-22, \mathrm{Fe}_{2} \mathrm{O}_{3}: 8-15, \mathrm{MgO}: 4-19$, $\mathrm{CaO}: 20-43, \mathrm{CO}_{2}: 15-32, \mathrm{~K}_{2} \mathrm{O}: 0.2-1.3, \mathrm{Na}_{2} \mathrm{O}:$ $0.01-0.3, \mathrm{P}_{2} \mathrm{O}_{5}: 1.6-3.3$, and trace elements as well (Fig.5). It could be explained by significant variation of mineral composition within magmatic layered rocks. Nevertheless, chemical composition and characteristic element ratios as well as REE and trace elements patterns for studied carbonatite kimberlite are comparable not only with typical group I kimberlite (South Africa) but with alkaline-ultramafic-carbonatite rocks such as Sung Valley complex (Northeast India).

To estimate the age of carbonatite kimberlite dyke from Fisher Massif we have separated accessory zircon from one sample. Total number of separated grains was ca 20 from the sample about $2 \mathrm{~kg}$. They were represented by particles of large transparent and weakly colored crystals of magmatic morphology (Fig.6a, b). CL images are typical for zircons of alkaline-ultramafic rocks and kimberlites (Belousova et al., 1998, 2001) and are characterized by large block structure caused by repetition of dark and light zones corresponding to considerable fluctuation in $\mathrm{U}, \mathrm{Th}, \mathrm{Pb}$ and REE content which depends on peculiarities of zircon crystallization under conditions of fluid saturated kimberlite melt. U-Pb isotope compositions were measured in the 6 largest zircon grains by SIMS SHRIMP-II. The obtained results, in spite of essential 

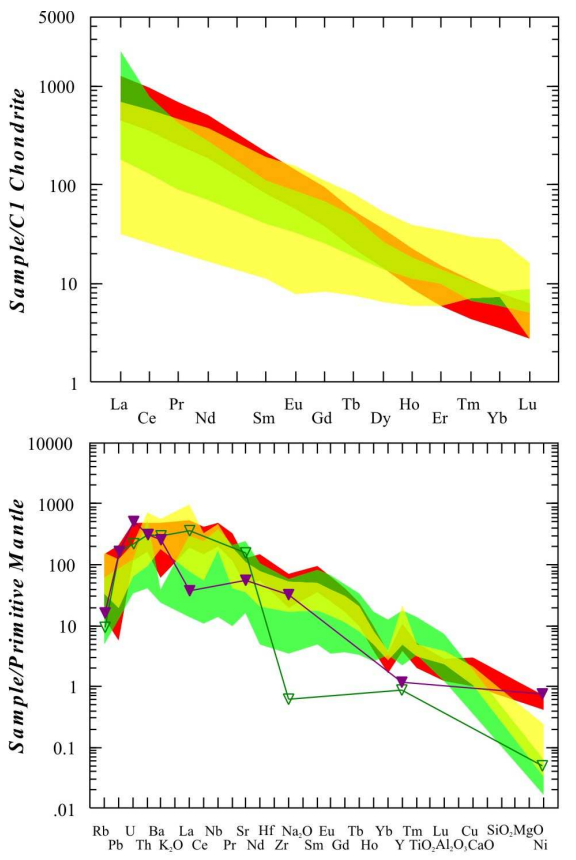

Group 1 kimberlites (Dutoitspan, Bultfontein, Wesselton Floor sills (South Africa))

Alkaline-ultrabasic carbonatite complex (pyroxenites, ijolites, carbonatite (Shillong, India)) Fisher Massif kimberlites (carbonatite kimberlites and picrites (East Antarctica))

$\nabla \nabla$ Benfontein kimberlitic sills (calcite rich layer and "normal" kimberlite (South Africa))

Fig. 5 REE and trace elements patterns of carbonatite kimberlite, South African group I kimberlites (LeRoex et al., 2003) and rocks of alkaline-carbonatite complex (Srivastava et al., 2005).

variations of element content [U]: $18-348 \mathrm{ppm},[\mathrm{Th}]$ : $5-1069 \mathrm{ppm},[\mathrm{Pb}]: 0.3-5.9 \mathrm{ppm}$ and the presence of non-radiogenic $\mathrm{Pb}$ up to $12 \%$, have allowed to construct discordia line and evaluate the age of zircon crystallization of $122.1 \pm 1.3 \mathrm{Ma}$ (Fig.6d). The obtained crystallization age estimation characterizes magmatic event, because not only $\mathrm{Th} / \mathrm{U}$ ratio $0.3-3.2$ is typical for magmatic zircons, but REE patterns in the studied zircons correspond to the typical magmatic fractionation at zircon crystallization from a melt (Fig.6c). At the same time, indicative crystallization peculiarity, like interaction of crystallizing zircon matrix with the fluid enriched by lithophile elements, results in formation of characteristic zones within the individual zircon grains with typical metasomatic carbonatite distribution of REE (Fig.6c). Also, for this kimberlite we have obtained mineral $\mathrm{Rb}-\mathrm{Sr}$ isochron which corresponds to the age $118.4 \pm 3.2 \mathrm{Ma}$ with ${ }^{87} \mathrm{Sr}^{86} \mathrm{Sr}_{\mathrm{i}}=0.704870$ that coincides well with the results of $\mathrm{U}-\mathrm{Pb}$ zircon dating. Initial isotope composition of the carbonatite kimberlite: $\varepsilon_{\mathrm{Nd}}=-0.96,{ }^{187} \mathrm{Os} /{ }^{186} \mathrm{Os}=$ 0.23351, $\quad{ }^{206} \mathrm{~Pb} /{ }^{204} \mathrm{~Pb}=18.339, \quad{ }^{207} \mathrm{~Pb} /{ }^{204} \mathrm{~Pb}=15.517$ evidences to weakly enriched mantle source of this kimberlite which could be accosiated with mantle plume existing in this region.

Taking into consideration the obtained data and supposing that the formation of this kimberlite is connected with development of Lambert-Amery rift in Mesozoic time and mantle activity under the influence of the Kerguelen plume (?) which caused Gondwana
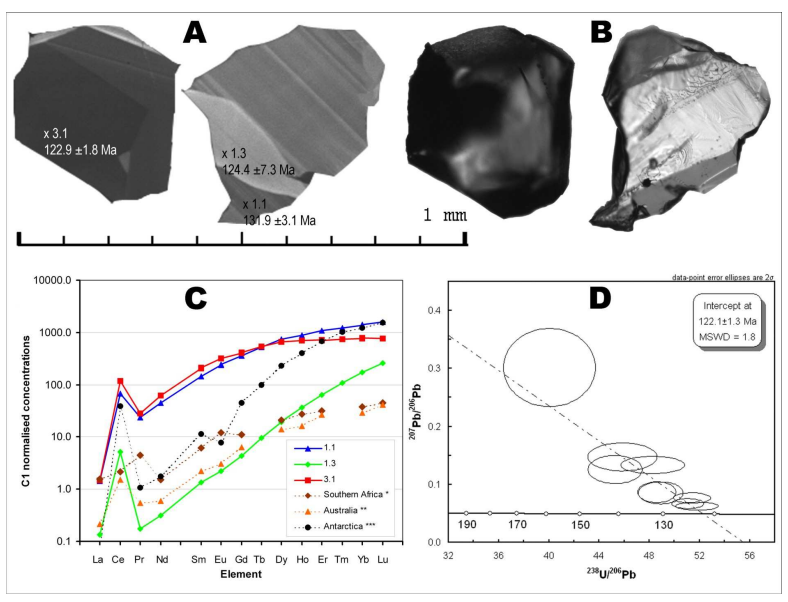

Fig. 6 Carbonatite kimberlite zircons, Fisher Massif. A, B CL and optic zircon images; C - REE patterns, numbers correspond to analytical points of $\mathrm{A}, *, * *$ - kimberlite zircons from Belousova et al. (1998, 2001), *** - Mawson charnockite zircon (Hoskin, Ireland, 2000); D - TeraWasserburg concordia diagram.

breakup, we suggest that all known alkaline-ultramafic bodies from the northern Prince Charles Mountains region make up a single magmatic province, similar in time and development to the alkaline-ultramaficcarbonatite Shillong Province in India.

\section{References}

Belousova, E.A., Griffin, W.L., Pearson, N.J., 1998. Trace element composition and cathodoluminescence properties of southern African kimberlitic zircons. Mineralogical Magazine, 62 (3), 355-366.

Belousova, E.A., Griffin, W.L., et al., 2001. Two age populations of zircons from the Timber Creek kimberlites, Northern Territory, as determined by laser-ablation ICPMS analysis. Australian Journal of Earth Sciences, 48, 757-765.

Dawson, J.B., Hawthorne, J.B., 1973. Magmatic sedimentation and carbonatitic differentiation in kimberlite sills at Benfontein, South Africa. Journal of the Geological Society, London, 129, 61-85.

Egorov, L.S., Melnik, A.Yu., Ukhanov, A.V., 1993. First finding of a kimberlite dyke containing syngenetic calcite carbonatite schlieren in Antarctica. Reports of USSR Academy of Sciences, 328, 230-233.

Haggerty, S.E., Fung, A., 2006. Orbicular oxides in carbonatitic kimberlites. American Mineralogist, 91, 14611472.

Hoskin, P.W.O., Ireland, T.R., 2000. Rare earth element chemistry of zircon and its use as a provenance indicator. Geology, 28, 627-630.

Kjarsgaard, B.A., Hamilton, D.L., 1988. Liquid immiscibility and the origin of alkali-poor carbonatites. Mineralogical Magazine, 52, 43-55.

Lapin, A.V., Vartiainen, H., 1983. Orbicular and spherulitic carbonatites from Sokli and Vuorijarvi. Lithos, 16, 53-60.

LeRoex, A.P., Bell, D.R., Davis, P., 2003. Petrogenesis of group I kimberlites from Kimberley, South Africa: evidence from bulk-rock geochemistry. Journal of Petrology, 44 (12), 2261-2286.

Srivastava, R.K., Heaman, L.M., et al., 2005. Emplacement age and isotope geochemistry of Sung Valley alkalinecarbonatite complex, Shillong Plateau, northeastern India: implications for primary carbonate melt and genesis of the associated silicate rocks. Lithos, 81, 33-54. 